\title{
ANALISIS PROSES PENGELOLAAN OBAT RSUD DI JAWA TIMUR DENGAN PENDEKATAN LEAN HOSPITAL
}

\author{
ANALYSIS OF DRUG MANAGEMENT PROCESS AT PUBLIC HOSPITAL IN EAST JAVA \\ USING LEAN HOSPITAL APPROACH
}

\author{
Novianti Fatli Azizah', Wakhid Slamet Ciptono ${ }^{2}$, Satibi ${ }^{3}$ \\ 1) Magister Manajemen Farmasi, Universitas Gadjah Mada, Yogyakarta \\ 2) Fakultas Ekonomika dan Bisnis Universitas Gadjah Mada, Yogyakarta \\ 3) Fakultas Farmasi Universitas Gadjah Mada, Yogyakarta
}

\section{ABSTRAK}

Proses pelayanan yang efisien erat kaitannya dengan proses pengelolaan obat yang efisien. Tujuan dari penelitian ini untuk mengidentifikasi aktivitas serta menganalisis akar penyebab masalah dari waste kritis dengan menggunakan pendekatan lean hospital pada proses pengelolaan obat di sebuah Rumah Sakit Umum Daerah di Jawa Timur. Penelitian ini bersifat deskriptif kualitatif yaitu melalui observasi, wawancara dan penelusuran dokumen pada bulan November-Desember 2016 dan Januari 2017, untuk mendapatkan identifikasi aktivitas seleksi, pengadaan dan distribusi. Waste kritis diperoleh melalui kuesioner pembobotan waste dari penilaian seluruh petugas yang terlibat dalam proses, untuk dilakukan analisis lebih lanjut. Future state mapping dibuat dengan menghilangkan unsur waste dari proses pengelolaan obat. Hasil penelitian: Value stream mapping menunjukkan waste di setiap tahapan proses pengelolaan obat yaitu waste of defect, waste of waiting, waste of inventory, waste of transportation, waste of motion, waste of overprocessing, waste of overproduction, dan waste of human potential. Kesimpulan: Sebagian besar tahapan dalam proses pengelolaan obat memiliki value added activity kurang dari 50\%. Analisis akar penyebab masalah dari waste kritis yaitu kesibukan dokter dalam pelayanan menyebabkan penundaan dalam pengisian formulir usulan dan tidak semua SMF memiliki sekretaris, perencanaan belum terfasilitasi oleh SIM, sistem yang memaksa input SPPH pada saat penyusunan PO e-purchasing, adanya perubahan harga obat yang mendadak, tidak adanya tenaga kasir di UPF, tidak ada pemisah resep di awal pelayanan, bentuk ruangan UPF 1 memanfaatkan fasilitas lama, CPO belum difasilitasi oleh SIM, mesin etiket hanya 1 unit dan belum optimal.

Kata kunci: Lean Hospital, Waste kritis, Pengelolaan Obat, Fishbone diagram

\section{ABSTRACT}

Efficient service processes are closely related to efficient drug management processes. The purpose of this research is to identify every activity and analyze the root cause of critical waste using lean hospital approach at public hospital in east java. This research is descriptive qualitative, through observation, interview, and document tracing on november-desember 2016 until januari 2017, to identify every activity of selection, procurement and distribution. Critical waste obtained through 'waste weighting questionnaire' from the assessment of all officers involved in the process, for further analysis. Future state mapping is made by eliminating waste element from drug management process. Results: value stream mapping shows that many wastes in every stage of drug management process, including waste of defect, waste of waiting, waste of inventory, waste of transportation, waste of motion, waste of overprocessing, waste of overproduction, and waste of human potential. Conclusions: most of the stages at drug management process have value added activity less than $50 \%$. The root cause analysis of the critical waste problem is doctor's busyness in their service causes a delay in completing the proposal form and not all SMF have secretaries, the planning has not been facilitated by the information system, SPPH must be input at the time of preparation of epurchasing order, no cashier at pharmacy, no prescription separator at the beginning of service, outpatient pharmacy using old facility, CPO not facilitated by system information yet, there is only 1 unit of etiquette machine and not proper yet.

Keywords: Lean Hospital, Critical Waste, Drug Management, Fishbone diagram.

Korespondensi :

Novianti Fatli Azizah

Magister Manajemen Farmasi, Universitas

Gadjah Mada

Email : noviantiazizah.85@gmail.com

\section{PENDAHULUAN}

Adanya era JKN dan beroperasinya BPJS Kesehatan menjadi suatu peluang dan tantangan untuk rumah sakit dalam meningkatkan kualitas pelayanan. Rumah sakit harus menciptakan dan mengelola suatu sistem untuk mempertahankan dan memuaskan pasien 
sebagai konsumen akhirnya. Berdasarkan audit kinerja oleh Badan Pengawas Keuangan Jawa Timur pada Instalasi Farmasi tahun 2011, menunjukkan berbagai permasalahan terkait pengelolaan obat yang menyebabkan kekosongan persediaan. Beberapa metode untuk memperbaiki proses pelayanan dalam manajemen operasi (operations management), antara lain sistem lean enterprise, TQM dan six sigma, dapat digunakan bersama-sama dengan sistem lean enterprise sebagai kerangka kerja utama (Bozdogan et al., 2010). Dalam dunia sekarang ini, penerapan lean dalam bidang kesehatan sangat jelas. Lean adalah sebuah alat, sistem manajemen, dan filosofi yang merubah suatu rumah sakit menjadi lebih terorganisir dan teratur, yang memungkinkan rumah sakit untuk meningkatkan kualitas pelayanan terhadap pasien dengan cara mengurangi kesalahan dan waktu tunggu (Graban 2011). Beberapa contoh keberhasilan lean hospital yang cukup memuaskan antara lain : King Abdullah University Hospital, Yordania berhasil melakukan penghematan lebih dari $45 \%$ dalam siklus waktu pelayanan obat di unit farmasi rawat inap (Al-Araidah et al., 2010), Sebuah Rumah Sakit Umum di Italia berhasil menghemat biaya transportasi pasien IGD sebesar $€ 237.500 \quad$ (Chiarini 2013), Klinik Akademik Gynecologic Oncology Universitas Virginia berhasil menurunkan total waktu tunggu secara signifikan yaitu 119 menit menjadi 82 menit (Duska et al., 2015). Sebuah Klinik Cyctic Fibrosis di Amerika berhasil meningkatkan kunjungan pasien rawat jalan dengan durasi $\leq 60$ menit sebanyak $23 \%$, yaitu rata-rata waktu berkurang 10 menit perkunjungan, meningkatkan kapasitas menjadi 500 pasien per tahun serta tambahan pendapatan lebih dari $\$ 165.000$ per-tahun (Smith et al., . 2011), Klinik Akademik UroOncology University Health Network di Toronto berhasil meningkatkan value added time dari $30,6 \%$ menjadi $66,3 \%$ dari keseluruhan waktu kunjungan (Skeldon et al., 2014).

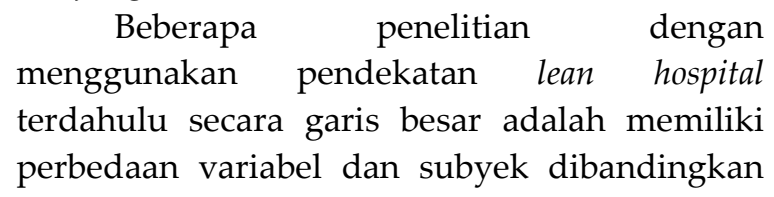

dengan penelitian ini, antara lain penelitian pada proses pengelolaan obat dengan prioritas pada pengadaan di RS Santa Maria Pemalang (Prasetya et al., 2015), proses pelayanan rawat jalan dan rawat inap di RSI Unisma Malang (Adellia et al., 2014), proses distribusi dan penyimpanan di RS PMI Bogor (Putri 2015). Tujuan dari penelitian ini adalah untuk mengidentifikasi aktivitas pada proses seleksi, pengadaan dan distribusi, serta menganalisis akar penyebab dari waste kritis pada proses pengelolaan obat sebuah Rumah Sakit Umum di Jawa Timur.

\section{METODE}

Penelitian ini bersifat deskriptif kualitatif dengan teknik pengambilan data dilakukan secara kualitatif dan kuantitatif. Teknik pengambilan data kualitatif diperoleh melalui wawancara dan data sekunder berupa dokumen pengelolaan obat, sedangkan data kuantitatif berupa angka (waktu) adalah data primer yang diambil melalui observasi proses pengelolaan obat serta kuesioner pembobotan waste. Kuesioner waste ini bertujuan untuk mendapatkan waste kritis yang akan dilakukan analisis lebih lanjut. Adapun kriteria inklusi populasi adalah pegawai rumah sakit yang terlibat dalam proses pengelolaan obat khususnya tahap seleksi, pengadaan dan distribusi, dengan kriteria eksklusi pegawai yang bertugas kurang dari 1 bulan. Metode dalam pengambilan sampel wawancara adalah purposive sampling dengan sampel observasi menggunakan prinsip redundancy artinya jika ditambah sampel lagi tidak memberikan informasi baru.

Pada tahap seleksi, observasi dilakukan sebanyak $1 x$ proses, karena seleksi dilakukan setiap tahun sekali. Pada tahap pengadaan, observasi dilakukan pada proses perencanaan dan pembelian obat bulan November 2016 yaitu pembelian yang dilakukan secara online (epurchasing) dan offline. Observasi proses pengadaan dilanjutkan hingga proses penerimaan dan pembayaran. Observasi pada tahap distribusi dilakukan pada distribusi obat dari gudang ke UPF (Unit Pelayanan Farmasi), dan distribusi obat di masing-masing UPF 


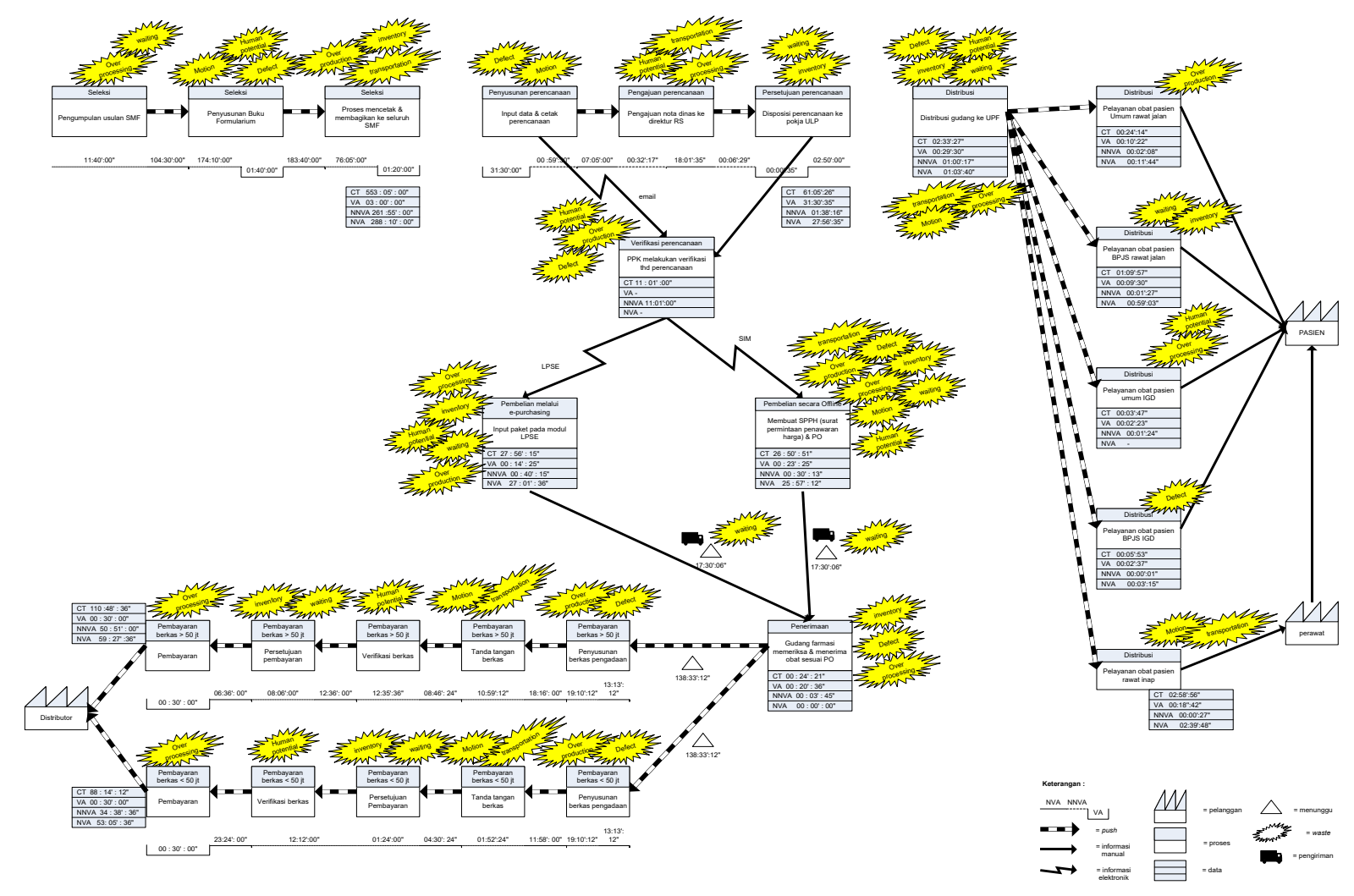

Gambar 1. Value Stream Mapping Proses Pengelolaan Obat

meliputi sistem distribusi resep perorangan pada rawat jalan dan IGD, serta sistem distribusi obat dosis unit pada rawat inap.

\section{HASIL DAN PEMBAHASAN}

Identifikasi Aktivitas Proses Pengelolaan Obat

Dalam melakukan identifikasi waste terlebih dahulu dilakukan identifikasi aktivitas ke dalam 3 kategori yaitu value added, necessary but non-value added dan non value added. Hasil dari identifikasi aktivitas digambarkan melalui value stream mapping (gambar 1) sehingga nampak dengan jelas cycle time dan waste apa saja yang terdapat di setiap proses. Cycle time adalah sejumlah waktu yang dibutuhkan untuk seorang dokter atau staf untuk menyelesaikan 1 pekerjaan atau urutan tugas dalam proses pelayanan kesehatan, meliputi aktivitas yang value added dan non-value added dalam siklus kerja (Jackson 2012).

Berdasarkan hasil identifikasi aktivitas (Tabel I) diketahui beberapa aktivitas yang tidak memberikan nilai, dalam hal ini dikelompokkan ke dalam 8 kategori waste. Tujuan dari lean thinking adalah untuk menciptakan nilai yang didefinisikan oleh pelanggan, dimana dalam hal pelayanan kesehatan, yang menjadi pelanggan utama adalah pasien (Dart 2011). Pada penelitian ini tidak dilakukan identifikasi value dengan menanyakan langsung kepada pasien, namun value yang diinginkan oleh pasien dapat diketahui dari beberapa penelitian terdahulu. Customer value dari 5 rumah sakit di Canada yaitu diagnosis yang akurat, serta perawatan sesuai tanpa kesalahan dan tanpa membuang waktu Fine et al., 2009).

Belum banyak penelitian yang identik dengan penelitian ini, oleh karena itu keseluruhan data tidak dapat dikomparasikan satu persatu. Jika dibandingkan dengan penelitian lain, maka diketahui value added pada proses pengadaan adalah 7,68 \% dari keseluruhan proses (Prasetya et al., 2015), dimana proses pengadaan antara rumah sakit swasta dan pemerintah berbeda berkaitan dengan proses birokrasi yang harus dilalui. 
Tabel I. Hasil Identifikasi Aktivitas Proses Pengelolaan Obat

\begin{tabular}{lccc}
\hline \multicolumn{1}{c}{ Proses } & \multicolumn{2}{c}{ \% aktivitas } \\
\cline { 2 - 4 } & VA & NNVA & NVA \\
\hline Seleksi & 0,54 & 47,36 & 52,10 \\
Perencanaan & 51,58 & 2,68 & 45,74 \\
Verifikasi perencanaan & 0 & 100 & 0 \\
Pembelian secara e-purchasing & 0,86 & 2,40 & 96,74 \\
Pembelian secara offline & 1,45 & 1,88 & 96,67 \\
Penerimaan & 84,60 & 15,4 & 0 \\
Pembayaran berkas >50 juta & 0,45 & 45,89 & 53,66 \\
Pembayaran berkas <50juta & 0,57 & 39.26 & 60,17 \\
Distribusi obat dari gudang ke UPF & 19,22 & 39,29 & 41,49 \\
Distribusi obat pasien umum rawat jalan & 42,75 & 8,82 & 48,43 \\
Distribusi obat pasien BPJS rawat jalan & 13,59 & 2,08 & 84,40 \\
Distribusi obat pasien umum IGD & 62,88 & 37,12 & 0 \\
Distribusi obat pasien BPJS IGD & 44,37 & 0,34 & 55,29 \\
Distribusi obat pasien rawat inap (UDD) & 9,38 & 1,32 & 89,30 \\
\hline
\end{tabular}

Tabel II. Rekapitulasi Hasil Identifikasi Aktivitas

\begin{tabular}{lccccccc}
\hline & \multicolumn{3}{c}{ Current } & \multicolumn{4}{c}{ Future } \\
\cline { 2 - 7 } \multicolumn{1}{c}{ Tahap } & \multicolumn{3}{c}{ Waktu (menit) } & Waktu (menit) & \% \\
\cline { 2 - 7 } & Wait & Cycle & Lead & Wait & Cycle & Lead & Hemat \\
& time & time & time & time & time & time & CT \\
\hline Seleksi & 0 & 33.185 & 33.185 & 0 & 12.400 & 12.400 & 62,63 \\
Perencanaan & 0 & 3.665 & 3.665 & 0 & 1.988 & 1.988 & 45,77 \\
Verifikasi perencanaan & 0 & 661 & 661 & 0 & 661 & 661 & 0 \\
e-purchasing & 0 & 1.676 & 1.676 & 0 & 55 & 55 & 96,74 \\
Pembelian secara offline & 0 & 1.611 & 1.611 & 0 & 23 & 23 & 98,55 \\
Penerimaan & 1.050 & 24 & 1.074 & 125 & 24 & 149 & 0 \\
Pembayaran berkas $>$ 50 juta & 8.313 & 6.649 & 14.962 & 0 & 1.931 & 1.931 & 70,96 \\
Pembayaran berkas $\leq 50 j u t a$ & 8.313 & 5.294 & 13.607 & 0 & 958 & 958 & 81,90 \\
distribusi obat dari gudang & 0 & 153 & 153 & 0 & 90 & 90 & 41,48 \\
Distribusi obat pasien umum rawat jalan & 0 & 24 & 24 & 0 & 12 & 12 & 48,42 \\
Distribusi obat pasien BPJS rawat jalan & 0 & 70 & 70 & 0 & 11 & 11 & 84,36 \\
Distribusi obat pasien umum IGD & 0 & 4 & 4 & 0 & 4 & 4 & 0 \\
Distribusi obat pasien BPJS IGD & 0 & 6 & 6 & 0 & 3 & 3 & 55,52 \\
Distribusi obat pasien rawat inap (UDD) & 0 & 179 & 179 & 0 & 19 & 19 & 89,31 \\
\hline
\end{tabular}

Pada alur proses distribusi gudang, 47\% merupakan langkah yang tidak mempunyai nilai tambah (Putri 2015). Selain itu value added activity pada distribusi obat di satelit farmasi rawat jalan adalah $45 \%$ dan di rawat inap adalah 31\% (Nancy 2014). Hasil identifikasi aktivitas ini akan berbeda di setiap rumah sakit, tergantung dengan kebijakan dan regulasi yang diterapkan.
Future state value stream mapping mengilustrasikan bagaimana proses seharusnya bekerja atau dapat bekerja jika didesain ulang, yang menunjukkan langkah proses lebih sedikit (setelah disederhanakan), tingkat kompleksitas yang sedikit dalam aliran informasi, dan waktu tunggu yang lebih singkat antar langkah². Dengan mempertimbangkan beberapa usulan perbaikan dan menghilangkan unsur waste, 
maka diperoleh gambaran future state value stream mapping yang mendekati proses ideal dan penghematan cycle time (CT) (Tabel II).

\section{Analisis Akar Penyebab Waste Kritis}

Setiap aktivitas dilakukan identifikasi dan pembobotan waste, sehingga diketahui waste paling kritis dari setiap proses seleksi, pengadaan dan distribusi. Dalam menentukan waste kritis dilakukan perhitungan rata-rata dari nilai yang diberikan oleh petugas dalam kuesioner waste. Usulan perbaikan dapat diprioritaskan pada waste paling kritis yang terlebih dahulu dicari akar penyebab masalahnya.

Pada proses seleksi diketahui bahwa waste yang paling sering terjadi adalah waste waiting yaitu pada aktivitas menunggu SMF mengumpulkan usulan formularium. Dengan menggunakan metode fishbone diagram diketahui bahwa kesibukan dokter dalam memberikan pelayanan kepada pasien menyebabkan terjadi penundaan dalam pengisian formulir usulan. Selain itu juga disebabkan SMF tidak seluruhnya memiliki sekretaris yang bisa membantu proses administrasi termasuk pengumpulan data ilmiah yang diperlukan. Proses seleksi adalah salah satu proses yang penting dalam pengelolaan obat, karena menjamin pasien untuk memperoleh obat yang ekonomis dan berkualitas. Usulan perbaikan dalam rangka merubah perilaku SMF, yaitu perlu dilakukan ketegasan terkait aturan dari ketua KFT dengan mengetahui Direktur, tentang batas waktu pengajuan usulan formularium disertai dengan kriterianya serta menegaskan sanksi yang tegas jika melewati batas waktu yang ditentukan. Dalam hal ini KFT bertanggungjawab dalam mengatur sistem formularium, memberikan evaluasi, pendidikan dan konsultasi kepada staf medis dan administrasi organisasi, mengawasi kebijakan dan prosedur (Tyler, et al., 2008).

\section{Analisis akar penyebab dari waste kritis pada proses pengadaan}

Apoteker menyusun perencanaan secara manual, karena belum terfasilitasi oleh
SIM, padahal sistem informasi yang terdapat di Instalasi Farmasi sudah terintegrasi antar unit serta data yang diperlukan sudah tersedia.

Perlu pembuatan SPPH (Surat Permintaan Penawaran Harga) sebelum PO (purchase order) pada pengadaan secara online. Aktivitas ini disebabkan sistem pada SIM yang memaksa petugas harus melakukan input SPPH pada saat penyusunan $\mathrm{PO}$.

Mengirimkan SPPH setiap bulan dan menunggu distributor mengirimkan penawaran harga (pada pengadaan secara offline). Kedua waste kritis ini terjadi secara berurutan dimana aktivitas menunggu penawaran merupakan lanjutan dari kegiatan ULP mengirimkan SPPH ke distributor. Adapun yang menyebabkan ULP mengirimkan SPPH setiap bulan adalah adanya perubahan harga obat pada distributor yang mendadak, tidak diinformasikan kepada ULP maupun ke gudang farmasi.

\section{Usulan perbaikan untuk waste kritis pada proses pengadaan}

Perlu dilakukan perubahan alur proses pengadaan, dimana dokumen pengadaan dibuat di awal, ditempuh dengan adanya koordinasi yang baik antara PPK (Pejabat Pembuat Komitmen) dengan distributor, termasuk kesepakatan sanksi untuk keterlambatan. Semua hal terkait ketentuan selama proses pengadaan dicantumkan secara jelas dalam dokumen pengadaan termasuk waktu rencana pengiriman obat (jika dilakukan dalam beberapa termin). Penerapan alur proses pengadaan baru ini diharapkan dapat menghilangkan wait time antara proses penerimaan dan pembayaran, sehingga mengurangi potensi terjadinya permasalahan ketersediaan obat pada periode pengadaan berikutnya.

Memberlakukan kontrak harga untuk kurun waktu tertentu, ULP tidak perlu lagi mengirimkan SPPH setiap bulan, proses menunggu penawaran dapat dihilangkan. Sehingga proses pengadaan secara offline jadi lebih singkat.

Perlu dilakukan evaluasi dalam perencanaan menggunakan metode ABC-VEN. Kelompok obat $C$ dengan NIK 4-6,4 frekuensi 
pemesanan dapat dilakukan lebih jarang, disesuaikan dengan kebutuhan dan dana, serta pengawasan terhadap kelompok ini dapat lebih longgar, misalnya 6-12 bulan sekali ${ }^{16}$. Selain itu input data pemakaian dan stok pada proses perencanaan sebaiknya terfasilitasi melalui SIM farmasi.

Membuat akses khusus untuk pembuatan PO e-purchasing pada SIM dengan menghilangkan proses SPPH.

\section{Analisis akar penyebab dari waste kritis pada proses distribusi}

Tenaga Teknis Kefarmasian merangkap sebagai kasir karena tidak ada tenaga keuangan yang ditempatkan di farmasi.

Petugas menyiapkan semua resep termasuk obat yang ditinggal oleh pasien BPJS rawat jalan, karena tidak dilakukan pemisahan di awal pelayanan.

Pasien BPJS rawat jalan berjalan menuju ruang tunggu, disebabkan bentuk ruangan UPF 1 memanfaatkan fasilitas lama yang sudah ada. Loket penerimaan resep untuk pasien BPJS rawat jalan bersebelahan dengan loket penerimaan resep untuk pasien umum rawat jalan di UPF 1.

Dilakukan penulisan CPO (catatan pengambilan obat), dan masih ditulis manual, karena belum difasilitasi oleh SIM. CPO digunakan sebagai pengingat obat yang diberikan sebelumnya pada tanggal berapa, untuk menyesuaikan dengan batasan restriksi. CPO ini seringkali dihilangkan oleh pasien, sehingga petugas terpaksa menuliskan ulang.

Etiket ditulis manual, karena hanya ada 1 unit mesin cetak etiket dan belum optimal, hasil cetak masih perlu dilakukan edit manual.

\section{Adapun usulan perbaikan dari waste kritis proses distribusi}

Perubahan alur pasien pulang rawat inap. Dengan menerapkan alur ini, UPF rawat inap dapat melayani pasien umum seperti pasien asuransi biasa, dan melakukan entry resep seperti pasien asuransi (kredit). Transaksi akan terbaca oleh kasir rawat inap pada saat pasien diijinkan untuk pulang, dengan demikian TTK di UPF tidak perlu melakukan transaksi keuangan.

Pemisahan resep di awal dan tupoksi baru petugas penerima resep BPJS rawat jalan. Pada umumnya pasien yang sering meninggalkan resep adalah pasien yang akan mengambil hasil laboratorium atau radiologi keesokan hari, atau pasien rehabilitasi medik yang akan melakukan perawatan tiap 2-3 hari sekali. Dengan demikian usulan tupoksi tersebut adalah : (1) Menerima resep, (2) Memeriksa kelengkapan untuk persyaratan klaim BPJS, (3) Menanyakan apakah resep akan ditunggu atau ditinggal, kemudian memisahkan resep, (4) Memberikan nomor antrian, (5) Menginformasikan bahwa resep akan ditumpuk sesuai antrian.

Pemindahan loket penyerahan resep pasien BPJS rawat jalan. Desain tata letak fasilitas untuk apotek rumah sakit dievaluasi dengan menggunakan sistem penilaian tertimbang untuk mengidentifikasi rancangan yang lebih unggul dari tata letak saat ini dan tata letak alternatif, antara lain dalam hal aspek kelayakan, dimana berhubungan dengan ketersediaan budget untuk melakukan desain ulang ruangan (McDowell and Huang 2012). Oleh karena itu yang paling memungkinkan dilakukan dalam waktu dekat adalah desain ulang ruangan dan alur pasien pada UPF1. Desain dan alur baru yang diterapkan di UPF 1 yaitu memindahkan loket penyerahan resep pasien BPJS rawat jalan menjadi bersebelahan dengan loket penyerahan obat. Dengan demikian pasien tidak perlu berputar setelah menyerahkan resep menuju ruang tunggu penyerahan obat, serta terpisah dari ruang tunggu pasien umum.

Memfasilitasi CPO dalam SIM farmasi yang tercetak bersama dengan kwitansi setelah dilakukan entry resep, sehingga tenaga farmasi dapat dialihkan untuk membantu petugas yang menyiapkan obat (peracikan).

Menambah mesin cetak etiket untuk ditempatkan di seluruh unit farmasi, dan memfasilitasi cetak melalui SIM farmasi meskipun tanpa melalui e-prescribing. Hal ini dapat mengurangi terjadinya batching (tumpukan) resep pada proses menunggu obat 
diberi etiket, dan tenaga farmasi dapat dialihkan untuk membantu peracikan sehingga mengurangi waktu tunggu.

Mengoptimalkan sistem e-prescribing dengan aplikasi yang memudahkan pengguna, oleh karena itu perlu dilakukan sosialisasi dan pelatihan agar semua pihak yang terkait menjadi paham hingga terbiasa menggunakan. Salah satu alat yang berpotensi untuk mendukung patient care dan meningkatkan medication safety adalah e-prescribing. Lebih lanjut, teknologi tersebut meringankan apoteker dari aktivitas distribusi yang lama sehingga apoteker dapat mencurahkan waktu lebih banyak untuk memberikan pelayanan langsung kepada pasien (Alsultan et al., 2012). Adanya eprescribing ini diharapkan mampu mengurangi waktu tunggu pada awal proses pelayanan resep akibat batching (tumpukan resep), terutama pada unit rawat inap. Penggunaan $e$ prescribing juga dapat menghasilkan efisiensi dalam mengurangi aktivitas dokter dan apoteker yang berlebihan, serta apoteker dapat memeriksa e-prescribing yang masuk untuk mengatur persediaan obat dengan lebih baik dan menyediakan obat dengan tepat waktu (Zadeh, et al., 2016). E-prescribing yang dikirimkan oleh dokter pada saat kunjungan pasien, memungkinkan apoteker untuk mengatur dengan lebih baik resep mana yang dilayani terlebih dahulu, karena pasien tidak lagi membawa resep ke farmasi dan menunggu untuk dilayani. Hal ini menunjukkan penghematan waktu potensial yang terbesar untuk pasien (Lanham, et al., 2016).

\section{KESIMPULAN}

Sebagian besar tahapan dalam proses pengelolaan obat memiliki value added activity kurang dari 50\%. Analisis akar penyebab masalah dari waste kritis yaitu kesibukan dokter dalam pelayanan menyebabkan penundaan dalam pengisian formulir usulan dan tidak semua SMF memiliki sekretaris, perencanaan belum terfasilitasi oleh SIM, sistem yang memaksa input SPPH pada saat penyusunan PO e-purchasing, adanya perubahan harga obat yang mendadak, tidak adanya tenaga kasir di UPF, tidak ada pemisah resep di awal pelayanan, bentuk ruangan UPF 1 memanfaatkan fasilitas lama, CPO belum difasilitasi oleh SIM, mesin etiket hanya 1 unit dan belum optimal.

\section{DAFTAR PUSTAKA}

1. Adellia Y, Setyanto NW, Farela C, Tantrika M. Pendekatan Lean Healthcare Untuk Meminimasi Waste Di Rumah Sakit Islam UNISMA Malang. J Rekayasa dan Manaj Sist Ind. 2014;2(2):292-301. jrmsi.studentjournal.ub.ac.id.

2. Al-Araidah O, Momani A, Khasawneh M, Momani M. Lead-time reduction utilizing lean tools applied to healthcare: the inpatient pharmacy at a local hospital. J Healthc Qual. 2010;32(1):59-66. doi:10.1111/j.1945-1474.2009.00065.x.

3. Alsultan MS, Khurshid F, Mayet AY, AlJedai AH. Hospital pharmacy practice in Saudi Arabia: Dispensing and administration in the Riyadh region. Saudi Pharm J. 2012;20(4):307-315. doi:10.1016/j.jsps.2012.05.003.

4. Bozdogan K. Towards an Integration of The Lean Enterprise System, Total Quality Management, Six Sigma and Related Enterprise Process Improvement Methods. Encyclcopedia Aerosp Eng. 2010;6:1-23.

doi:10.1002/9780470686652.eae371.

5. Chiarini A. Waste savings in patient transportation inside large hospitals using lean thinking tools and logistic solutions. Leadersh Heal Serv. 2013;26(4):356-367. doi:10.1108/LHS-052012-0013.

6. Dart RC. Can lean thinking transform American health care? Ann Emerg Med. 2011;57(3):279-281.

doi:10.1016/j.annemergmed.2010.11.027.

7. Duska LR, Mueller J, Lothamer $\mathrm{H}$, Pelkofski EB, Novicoff WM. Lean methodology improves efficiency in outpatient academic Gynecologic Oncology clinics. In: Gynecologic Oncology. Vol 138. ; 2015:707-711. doi:10.1016/j.ygyno.2015.07.001. 
8. Esmaeil Zadeh P, Tremblay MC. A review of the literature and proposed classification on e-prescribing: Functions, assimilation stages, benefits, concerns, and risks. Res Soc Adm Pharm. 2016;12(1):1-19.

doi:10.1016/j.sapharm.2015.03.001.

9. Fine B, Golden B, Hannam R, Morra D. Leading Lean: A Canadian Healthcare Leader's Guide. Healthc Q. 2009;12(3):3241. doi:10.12927/hcq.2013.20877.

10. Graban M. Lean Hospitals: Improving Quality, Patient Safety, and Employee Engagement, Second Edition. Boca Raton: CRC Press; 2011.

11. Jackson TL. Standard Work for Lean Healthcare. New York: CRC Press; 2012.

12. Lanham A, Cochran GL KD. Electronic Prescriptions: Opportunities and Challenges for the Patient and Pharmacist. Adv Heal Care Technol. 2016;2:1-11.

doi:https://doi.org/10.2147/AHCT.S64477

13. Mcdowell AL, Huang YL. Selecting a pharmacy layout design using a weighted scoring system. Am J Heal Pharm. 2012;69(9):796-804. doi:10.2146/ajhp100687.

14. Nancy. Pendekatan Lean Hospital Untuk Perbaikan Berkelanjutan (continuous
Improvement) Proses Pelayanan Instalasi Farmasi RS Bethesda Yogyakarta. 2014.

15. Prasetya TLT, Kristin E, Lestari T. Waste in drug procurement process in pharmacy department Santa Maria hospital Pemalang, Indonesia. Int J Pharm Sci Rev Res. 2015;31(1):174-178.

16. Putri EI. Analisis Lean Six Sigma Perbekalan Farmasi di Gudang Farmasi RS PMI Bogor Tahun 2013. J Adm Rumah Sakit Indones. 2015;1(2):59-69.

17. Satibi. Manajemen Obat Di Rumah Sakit. Yogyakarta: Universitas Gadjah Mada Press; 2015.

18. Skeldon, S. C., Simmons, A., Hersey, K. et al. Lean Methodology Improves Efficiency in Outpatient Academic Urooncology Clinics. Urology. 2014;83(5):992998. doi:10.1016/j.urology.2013.11.048.

19. Smith C, Wood S, Beauvais B. Thinking lean: implementing DMAIC methods to improve efficiency within a cystic fibrosis clinic. $J$ Healthc Qual. 2011;33(2):37-46. doi:10.1111/j.19451474.2010.00130.x.

20. Tyler LS, Cole SW, May JR, et al. ASHP Guidelines on the Pharmacy and Therapeutics Committee and the Formulary System. Am J Heal Pharm. 2008;65(13):1272-1283. doi:10.2146/ajhp080086. 